\title{
Effects of organic manure and crop rotation system on potato (Solanum tuberosum L.) tuber yield in the highlands of Awi Zone
}

\author{
Agegnehu Shibabaw ${ }^{1 *}$, Getachew Alemayehu ${ }^{1}$, Enyew Adgo ${ }^{1}$, Folkard Asch $^{2}$ and Bernhard Freyer ${ }^{3}$ \\ ${ }^{1}$ Bahir Dar University, College of Agriculture and Environmental Sciences, Ethiopia \\ ${ }^{2}$ University of Hohenheim, Germany \\ ${ }^{3}$ University of Natural Resources and Life Sciences, Austria
}

\begin{abstract}
Lack of sustainable soil fertility management system is a critical challenge in the highlands of Awi Zone. Important physicochemical properties of the soil are below the critical level to support crop growth. Hence, a study was undertaken with the aim of improving the yield of potato through organic treatments and sound crop rotation system. Two rotation systems and four levels of organic treatments were factorially arranged and laid out in RCBD with four replications. The organic treatments were: $\mathrm{V} 1=0 \mathrm{t} / \mathrm{ha}$ farmyards manure $(\mathrm{FYM}) ; \mathrm{V} 2=2.5 \mathrm{t} / \mathrm{h}$ fresh sesbania green manure (FSB) V3 $=5 \mathrm{t} / \mathrm{ha} \mathrm{FYM}$; and V4 $=5 \mathrm{t} / \mathrm{ha} \mathrm{FYM}+2.5 \mathrm{t} / \mathrm{ha} \mathrm{FSB}$ applied in fixed plots for three years. Indeed, the rotation systems varied from year to year to estimate the changes in potato tuber yields due to the differences in crop rotation systems. Tuber yields of potato showed increasing trend over the period of the three years with the lowest in the first year, intermediate in the second year and the highest in the third year across all treatments. Among all, the highest total potato tuber yield $(35.15 \mathrm{t} / \mathrm{ha})$ was obtained at the combined application of $5 \mathrm{t} / \mathrm{ha} \mathrm{FYM}+2.5 \mathrm{t} / \mathrm{ha} \mathrm{FSB}$ and clover-wheat-potato rotation system in the third year. The treatment combination increased total potato tuber yield by $140 \%$ and $41 \%$ over that of the first and the second years and would be recommended as ecologically sound option in improving the productivity of potato.
\end{abstract}

Keywords: Cropping system; farmyard manure; green manure; productivity; soil management DOI: http://dx.doi.org/10.4314/ejst.v11i1.1

\section{INTRODUCTION}

The highlands of Ethiopia account only $44 \%$ of the total area of the country, "although $90 \%$ of the human and $75 \%$ of the livestock population of the country is found in them" (Mohammed Gedefaw and Teshome Soromessa, 2015). The unbalanced livestock and human population pressure resulted in severe land degradation and soil nutrient depletion that has attributed to low agricultural productivity (Amare et al., 2006). Similarly, in the highlands of Awi Zone exploitative conventional agricultural practices such as continuous cropping with the entire removal of crop residues, abandoning of fallowing, reduced use of manure and crop rotation are further impoverishing soil resources of the region (Yazie Chanie, 2009). Tilahune et al. (2007) indicated that the use of dry animal manure and crop residues for the household energy source is also partly responsible for the declining of soil fertility in the highlands of Awi Zone.

Potato (Solanum tuberosum L.) is a very important crop in the highlands of Awi Zone. It has been widely renowned for improving the livelihood of smallholder farmers and sustains their food security at the household level (Glidermacher et al., 2009). However, the average national productivity of potato $(11.07 \mathrm{t} / \mathrm{ha})$ remains

\footnotetext{
*Corresponding author: agegnehus@yahoo.com

(C) This is an Open Access article distributed under the terms of the Creative Commons Attribution License (http://creativecommons.org/licenses/CC BY4.0).
} 
stagnant which is far below that of the world's average productivity of $17.67 \mathrm{t} / \mathrm{ha}$ (FAOSTAT, 2013). Lack of sustainable soil fertility management is partly responsible for the lower productivity of potato in the country in general and in Awi Zone in particular (Tilahune et al., 2007; Glidermacher et al., 2009; Hirpa et al., 2010).

Attempts to optimize sustainable nutrient supply in potato fields need diverse approaches of using organic inputs (Najme et al. 2013). Focusing on utilizing organic inputs are the key solution to reverse the declining trend of soil fertility, environmental threat and ultimately improve the profitability and the yield quality of potato (Goffart and Olivier, 2008). In cultivated lands, the primary organic input sources are the in-situ maintenance of crop residues and addition of farmyard manure to the soil. Another potential source of organic fertilizer in the present study area is using green manure such as clover and lupine undersowing with cereals or grown in pure stands in the rotation system. The important soil quality parameters such as the organic matter of the soil, soil nutrients, soil aeration and water holding capacity would be improved that in turn make the crop production more sustainable (Ndayegamiye et al. 2017). Hence, complementing of organic fertilizers with sound crop rotation systems would make the cropping systems more sustainable over the use of synthetic fertilizers.

Several research results underscore the importance of adding organic fertilizer in improving the yield of potato. Malihe et al. (2015) showed that application of farmyard manure at $40 \mathrm{t} / \mathrm{ha}$ significantly increased the tuber yield of potato (40 t/ha) by four folds over the yield (10.5 t/ha) on the unfertilized control. Similarly, Nooruldeen and Hiawe (2015) reported that application of well- prepared organic fertilizer at the optimal rate $(20 \mathrm{t} /$ ha) gave an equivalent tuber yield of potato to that of $100 \%$ mineral fertilizer. In addition, Sayed et al. (2014) indicated that organic production of potato using $23.8 \mathrm{t} / \mathrm{ha}$ of compost could be an alternative to the conventional production with commercial organic fertilizers without significant reduction in yield and quality.

Like that of farmyard manure, green manure in pure stand or in undersowing culture improved the tuber yield of potato by improving the fertility and ameliorating soil physical properties of the cultivated lands (Malihe et al. 2015). Eugenija et al. (2014) reported that the greatest tuber yield of potato was obtained after clover than barley rotation system. Similarly, Malihe et al. (2015) found that potato plants grown in plots following common vetch and faba bean produced $12.7 \%$ and $15.0 \%$ more tuber yield, respectively, compared with that of winter wheat. Stefano et al. (2010) indicated that clover green manure and farmyard manure substantially increased the total yield by $22.5 \%$ and $25.1 \%$, respectively, over the untreated control.

In the same way, farmyard manures and green manure crops are widely available in Awi Administrative Zone. Clover, lupine and sesbania have long been grown for years and can easily be used as green manure for potato production. Due to their very deep root penetration nature, high root biomass and ability to fix nitrogen biologically, inclusion of clovers in crop rotation schemes can play a great role in improving the properties of soils (Ruser et al., 2008). In low input cropping systems in general using organic fertilizers and sound crop rotation system may remarkably be improving crop productivity including potato on a more sustainable way. However, due to lack of 
awareness and intensive promotion of mineral fertilizer by extension system, the organic sources of fertilizers are not properly functioning in Awi Zone. Organic fertilizers are commonly used for other purposes such as fuel wood and plastering of houses than as source of nutrients. In addition, mono and continuous cropping are the dominant cropping systems in the study area which further diminish the fertility status of this area. In general, farmers of the locality have little experience in cultivating potato using their own farm resources. They rather rely on commercial sources of fertilizer which has a bearing on the sustainability of potato production.

In view of these backgrounds, the present study was initiated to assess the potential of organic treatments and sound crop rotation system without applying synthetic commercial fertilizers for improving the productivity of potato in the highlands of Awi Agro-Ecological Zone.

\section{MATERIALS AND METHODS}

\section{Descriptions of the Study Area}

The present study was carried out both at onstation and on-farm in Gusha Shinkurta rural village of Guagusa District, Awi Zone from 2013 to 2015. Geographically, the study area is located in northwestern Ethiopia in the ranges of $11^{\circ} 92^{\prime}$ to $11^{\circ} 91^{\prime} \mathrm{N}$ latitude and $28^{\circ} 61^{\prime}$ to $28^{\circ} 87^{\prime}$ E longitude. The altitude of the area ranges from 2451 to 2537 meters above sea level with a slope of 2.6 to $3.7 \%$ (Figure 1).

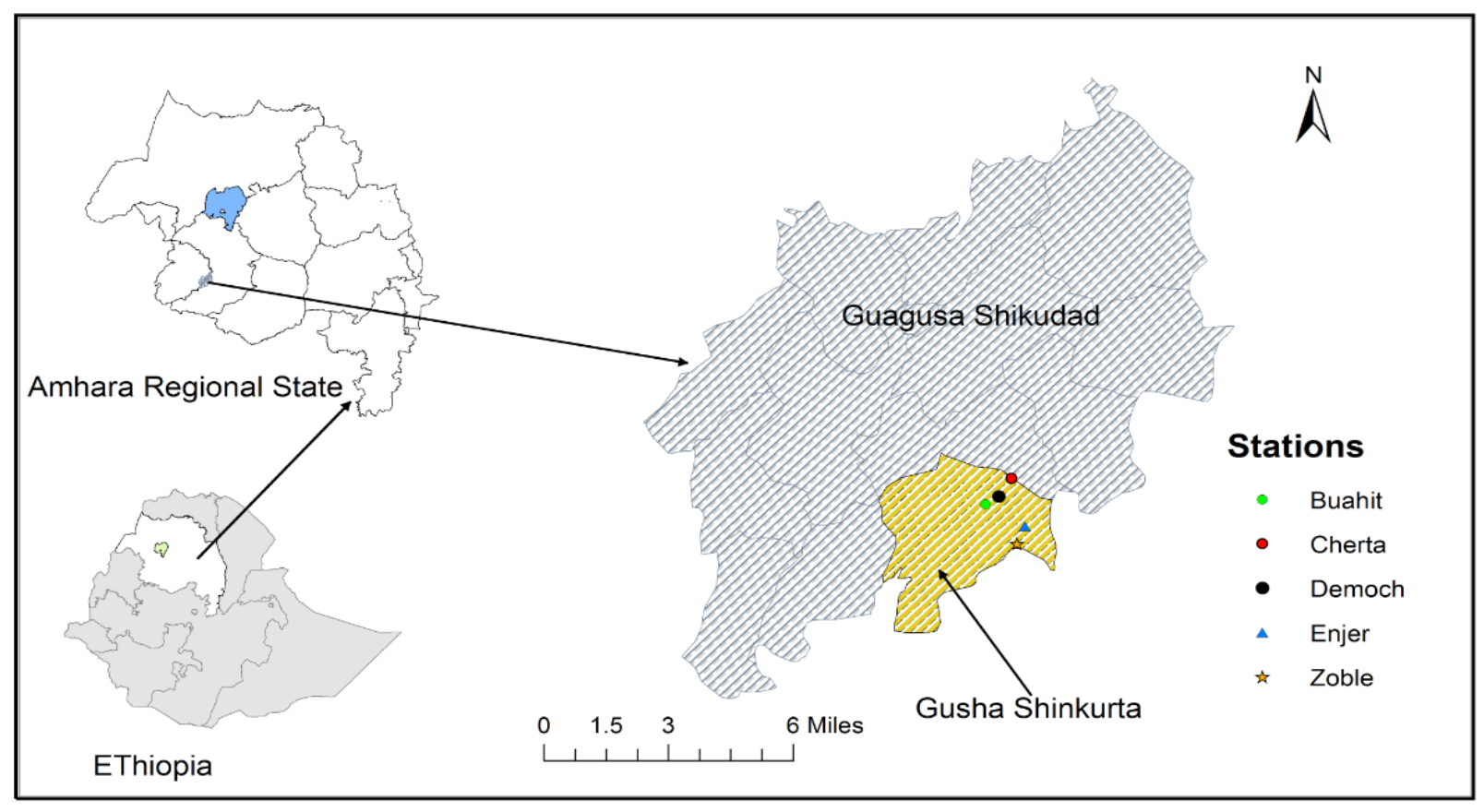

Figure 1: Location map of Guagusa Shikudad District, Gusha Shinkurta Village

The temperature of the area is cool with average night and day temperature of $10.2^{\circ} \mathrm{C}$ and $22.4^{\circ} \mathrm{C}$, respectively. Its average mean annual rainfall is
$2491.9 \mathrm{~mm}$ with mono-modal system extended from March to the end of November while the peak is in July and August (Figure 2). 


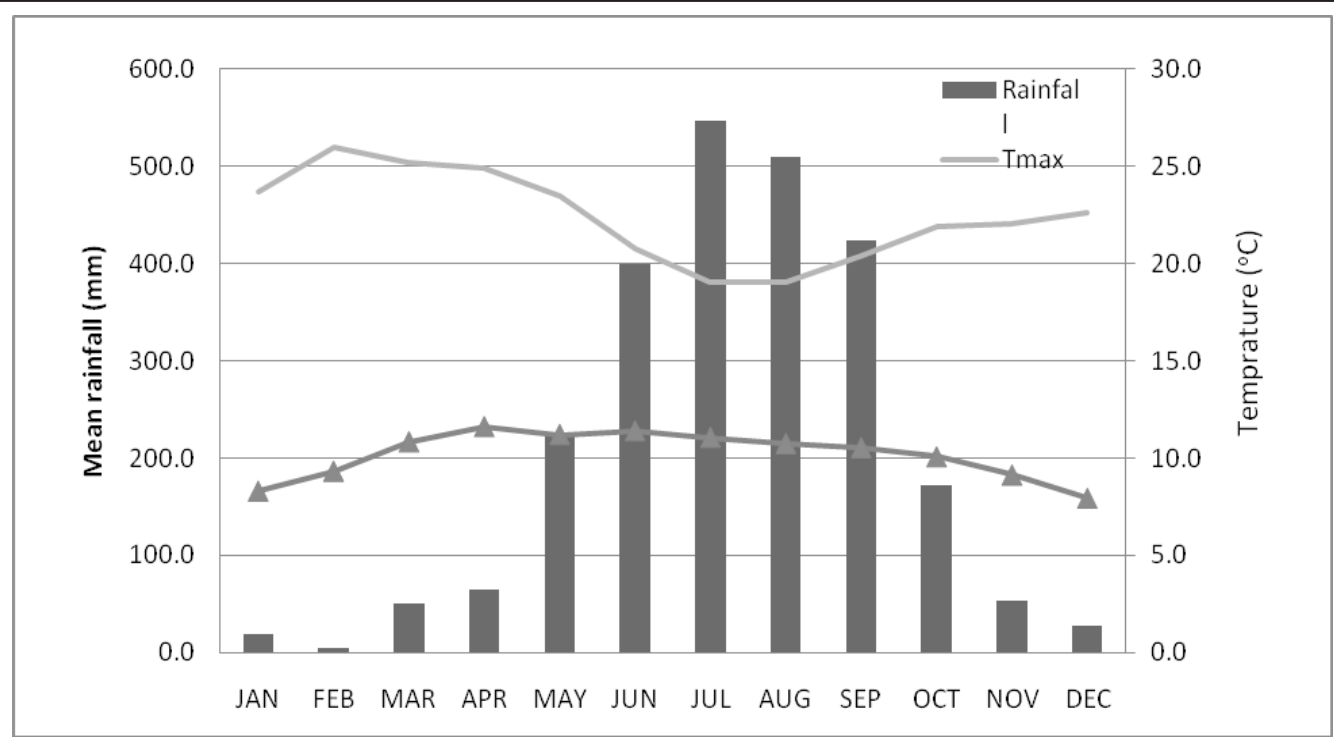

Figure 2: Average monthly rainfall and minimum and maximum temperatures of Gundile (nearby station)

The important physicochemical properties of the experimental soil were taken following the standard methods and procedures. Composite soil samples were initially taken just before starting the study at the plow depth of $0-20 \mathrm{~cm}$ and the results are presented in Table 1.

Table 1: Initial physicochemical properties of the experimental soil before commencing the study

\begin{tabular}{|c|c|c|c|c|c|c|c|}
\hline Soil parameters & Station & $\begin{array}{l}\text { On-farm } \\
\text { Site-1 }\end{array}$ & $\begin{array}{l}\text { On-farm } \\
\text { site-2 }\end{array}$ & $\begin{array}{l}\text { On- } \\
\text { farm } \\
\text { Site-3 }\end{array}$ & $\begin{array}{l}\text { On- } \\
\text { farm } \\
\text { Site-4 }\end{array}$ & Means & Category \\
\hline Total nitrogen $\%$ & 0.13 & 0.11 & 0.12 & 0.10 & 0.14 & 0.12 & low \\
\hline Available P (PPM) & 9.54 & 8.44 & 8.98 & 7.84 & 9.30 & 8.64 & low \\
\hline Exc. $\mathrm{K}$ cmol( $(+) \mathrm{kg}^{-1}$ soil & 0.68 & 0.65 & 0.65 & 0.70 & 0.71 & 0.68 & low \\
\hline Organic carbon $(\%)$ & 1.30 & 1.23 & 1.22 & 1.23 & 1.32 & 1.26 & low \\
\hline Organic matter $(\%)$ & 2.25 & 2.15 & 2.14 & 2.17 & 2.36 & 2.21 & low \\
\hline $\mathrm{pH}\left(\mathrm{H}_{2} \mathrm{O}\right)$ & 5.36 & 5.17 & 5.12 & 4.90 & 5.41 & 5.19 & strong \\
\hline $\mathrm{CEC}$ cmol $(+) \mathrm{kg}^{-1}$ soil & 16.10 & 14.08 & 16.66 & 13.96 & 17.40 & 15.64 & moderate \\
\hline Bulk density $\mathrm{g} \mathrm{cm}^{-3}$ & 1.36 & 1.37 & 1.38 & 1.39 & 1.35 & 1.37 & compacted \\
\hline Sand & 27.00 & 29.00 & 30.00 & 30.00 & 29.00 & 29.00 & \\
\hline Clay & 38.00 & 37.00 & 36.00 & 34.00 & 38.00 & 36.60 & \\
\hline Silt & 35.00 & 34.00 & 34.00 & 36.00 & 33.00 & 34.40 & \\
\hline \multirow{2}{*}{ Textural class } & clay & Clay & clay & clay & Clay & clay & \\
\hline & loam & Loam & loam & loam & loam & loam & \\
\hline
\end{tabular}

$\mathrm{CEC}=$ cation exchange capacity $\mathrm{P}=$ phosphorus; $\mathrm{K}=$ potassium; $\mathrm{ppm}=$ part per million; $\mathrm{pH}=$ potential of hydrogen

Following the standardizations of Murphy (1968), soils with $\mathrm{pH}(5.19)$ and organic carbon (1.26\%) were categorized as strongly acidic and low in standards, respectively. Similarly, soil with $0.12 \%$ nitrogen, $8.64 \mathrm{ppm}$ phosphorus and 0.678 cmol $(+) \mathrm{kg}^{-1}$ of soil potassium concentrations 
was categorized as low and the cation exchange capacity $\left(15.64 \mathrm{cmol}(+) \mathrm{kg}^{-1}\right.$ of soil) was moderate.

\section{Experimental Treatments and Design}

The treatment set up for an experiment varied from year to year to estimate the change in potato tuber yield of each year. Thus, in the first year, potato was planted with four different level of organic treatments $(\mathrm{V} 1=0 \mathrm{t} / \mathrm{ha} \mathrm{FYM} ; \mathrm{V} 2=2.5 \mathrm{t} /$ ha FSB; V3 $=5$ t/ha FYM and V4 $=5$ t/ha FYM $+2.5 \mathrm{t} / \mathrm{ha} \mathrm{FSB}$ ) in a completely randomized block design (RCBD) with four replications. In the second year, four level organic treatments $(\mathrm{V} 1=0 \mathrm{t} / \mathrm{ha} F Y M ; \mathrm{V} 2=2.5 \mathrm{t} / \mathrm{ha} \mathrm{FSB} ; \mathrm{V} 3=5 \mathrm{t} /$ ha FYM and V4 $=5$ t/ha FYM +2.5 t/ha FSB) were factorially combined with two rotation systems $(\mathrm{R} 1=$ wheat undersowing lupine in the first year and potato under sown lupine in the second year, and R2 = lupine in the first year and potato under sown lupine in the second year) in a completely randomized block design (RCBD) with four replications. In the third year again, the organic treatments $(\mathrm{V} 1=0 \mathrm{t} / \mathrm{ha} \mathrm{FYM} ; \mathrm{V} 2=2.5 \mathrm{t} /$ ha FSB; V3 $=5$ t/ha FYM and V4 $=5$ t/ha FYM $+2.5 \mathrm{t} / \mathrm{ha} \mathrm{FSB}$ ) were factorially combined with the two rotation systems $(\mathrm{R} 3=$ wheat under sown lupine in the first year, clover in the second year and potato in the third year, and $\mathrm{R} 4=$ clover in the first year, wheat under sown lupine in the second year and potato in the third year) in a completely randomized block design (RCBD) with four replications.

The gross size of the experimental plots was $3 \times 3$ $\mathrm{m}\left(9 \mathrm{~m}^{2}\right)$ with net harvesting plot area of $2.6 \times 2.6$ $\mathrm{m}\left(6.76 \mathrm{~m}^{2}\right)$. Adjacent plots within replications were separated with $0.5 \mathrm{~m}$ wide paths, while the spacing between adjacent replications was $1 \mathrm{~m}$. Sesbania branches and leaves were cut and chopped before incorporated into the soil. As per the treatments and the design, fresh Sesbania green manure and farmyard manure were uniformly broadcasted on the surface of the plots and incorporated immediately within $20 \mathrm{~cm}$ soil depth two weeks before planting. Clover as well as under sown lupine in wheat and potato plots were also chopped and incorporated into the soil at their 50\% flowering growth stages. Seed tubers of recently released potato variety "Belete" were used with recommended inter-row and intra-row spacing of $70 \mathrm{~cm}$ x $30 \mathrm{~cm}$, respectively.

Farmyard manure was produced with mixtures of fresh cow dung (55\%), sheep (35\%), chicken waste $(5 \%)$ and tree lucerne as bedding material $(5 \%)$. After maturation, the organic manure was analyzed for the nutrient concentration by collecting composite samples at top, middle and base of the pit and the results are presented in Table 2.

Table 2: Chemical contents of different manure sources used for the study

\begin{tabular}{llllllll}
\hline Manure source & $\mathrm{pH}\left(\mathrm{H}_{2} \mathrm{O}\right)$ & $\mathrm{CEC}$ & $\mathrm{OC} \%$ & $\mathrm{OM} \%$ & $\mathrm{~N} \%$ & $\mathrm{P} \%$ & $\mathrm{~K} \%$ \\
\hline Farmyard manure & 7.44 & 44.2 & 16.31 & 28.12 & 1.20 & 0.65 & 1.1 \\
Sesbania (Sesbania sesban) & & & & & 2.42 & 0.32 & 0.91 \\
Lupine (Lupinus albus) & & & & & 1.95 & 0.31 & 0.88 \\
Clover (Trifolium decoriom) & & & & & 2.17 & 0.43 & 0.89 \\
\hline
\end{tabular}

$\mathrm{p}^{\mathrm{H}}=$ potential of hydrogen; $\mathrm{CEC}=$ cation exchange capacity; $\mathrm{OC}=$ organic carbon; $\mathrm{OM}=$ organic matter; $\mathrm{N}$ $=$ nitrogen; $\mathrm{P}=$ phosphorus; $\mathrm{K}=$ potassium 


\section{Data Collection and Analysis}

Data of marketable, unmarketable and total tuber yields of potato were collected following their respective standard methods and procedures. The data were further subjected to analysis of variance (ANOVA) using General Linear Model (GLM) procedures of SAS version 9.1 (SAS, 2002). For parameters whose ANOVA results showed significant differences between treatments, mean separation was done using least significant difference (LSD) test at their respective level of error used for analysis of variance.

\section{RESULTS AND DISCUSSION}

\section{Potato Yield Trend}

Potato tuber yield was varied significantly $(P<0.01)$ in response to the main effects of organic treatments $(\mathrm{M})$ and crop rotation systems $(\mathrm{T})$ as well as their interaction ( $\mathrm{M} \times \mathrm{T})$ in each site and in combined over sites from 2013-2015.

The variation in level of organic treatments were significantly $(P<0.05)$ affected potato tuber yield in 2013 (Table 3). The highest marketable and total potato tuber yield were recorded at $5 \mathrm{t} / \mathrm{ha}$ FYM $+2.5 \mathrm{t} /$ ha FSM at both sites and in combined over sites. The marketable tuber yield (14.32 t/ ha) recorded was maximum at on-station plots. Similar to the on-station, the marketable yield $14.09 \mathrm{t} / \mathrm{ha}$ and $14.20 \mathrm{t} / \mathrm{ha}$ was also the maximum at on-farm conditions and in combined over the sites, respectively. The tuber yield in the station is a bit higher than that of on-farm condition due to the variation in initial soil conditions (Table 1). In addition, the total tuber yield of potato increased with the same scenario on the marketable yield of potato. FYM at $5 \mathrm{t} / \mathrm{ha}+2.5 \mathrm{t} / \mathrm{ha} \mathrm{FSM}$ showed the highest total potato tuber yield (14.69 t/ha) at onstation. Similarly, the total tuber yields of 14.49 and $14.59 \mathrm{t} / \mathrm{ha}$ were also superior at on-farm and in combined over sites, respectively. Following this treatment, FYM at $5 \mathrm{t} /$ ha showed better potato tuber yield with $11.32 \mathrm{t} / \mathrm{ha}$ at on-station; $13.49 \mathrm{t} / \mathrm{ha}$ at on-farm and $12.04 \mathrm{t} / \mathrm{ha}$ in combined over sites. The unfertilized control showed the minimum total potato tuber yield of $4.26,6.71$ and $5.49 \mathrm{t} / \mathrm{ha}$ at the station, on-farm and in combined over sites, respectively. The total tuber yield at a combination of manure increased by $165 \%$ compared to that of the unfertilized control.

The increase in potato tuber yield at $5 \mathrm{t} / \mathrm{ha}$ FYM $+2.5 \mathrm{t} / \mathrm{ha}$ FSM was due to the availability of more concentration of soil nutrients at the maximum level of organic treatments. The combination of manure contained the greatest quantity of $121,40.5 \& 73 \mathrm{t} / \mathrm{ha}$ of NPK, respectively, of soil nutrients compared to the lower levels (Appendix 1). The lowest yield on unfertilized control showed that the initial soil conditions were poorer to achieve modest potato tuber yield in Gusha soil conditions (Table 1).

Similarly, the increasing level of organics treatments and crop residue measurably increases the marketable and total tuber yield of potato in 2014 (Table 3). Thus, application of 5 t/ha FYM $+2.5 \mathrm{t} / \mathrm{ha}$ FSM resulted in the highest marketable tuber yield of 22.4, 24.4 and $23.36 \mathrm{t} / \mathrm{ha}$ at the station, on farm and in combined over sites, respectively. Like ways, the highest total potato tuber yields of $23.5 \mathrm{t} / \mathrm{ha}$ at station; $25.5 \mathrm{t} / \mathrm{haat}$ on-farm and $24.52 \mathrm{t} / \mathrm{ha}$ in combined over sites were recorded at $5 \mathrm{t} / \mathrm{ha}$ of FYM $+2.5 \mathrm{t} / \mathrm{ha} \mathrm{FSB}$. Following this treatment, FYM at 5 t/ha with 60 , $33 \& 50$ t/ha of NPK, respectively, showed greater 
total potato tuber yield of $22.60 \mathrm{t} / \mathrm{ha}$ at station; $23.30 \mathrm{t} / \mathrm{ha}$ at on-farm and $22.92 \mathrm{t} / \mathrm{ha}$ in combined over sites. The unfertilized control showed the lowest total tuber yield of 11.2, 10.4 and $10.8 \mathrm{t} / \mathrm{ha}$ potatoes at station, on-farm and in combined over sites, respectively.

Furthermore, the variation in levels of organic treatments significantly $(P<0.05)$ affected the tuber yield of potato at both sites and in combined over sites in 2015. Farmyard manure at $5 \mathrm{t} / \mathrm{ha}+2.5 \mathrm{t} /$ ha of FSB demonstrated the highest marketable tuber yield (29.52 $\mathrm{t} / \mathrm{ha})$ at the station. Similarly, the marketable yield (29.64 t/ha) was the greatest at on-farm conditions. The markatable yield (29.57 $\mathrm{t} / \mathrm{ha}$ ) recorded was also highest in combined over sites compared to other treatments in previous year. The trends of total potato tuber yields were similar to the marketable yield of potato. Total potato tuber yield of $31.43 \mathrm{t} / \mathrm{ha}$ was the largest at the station. In the same way, the total tuber yield of $31.55 \mathrm{t} / \mathrm{ha}$ was the biggest at the on-farm condition. Similarly, total tuber yield of $31.49 \mathrm{t} / \mathrm{ha}$ was the greatest in combined over sites. However, the unfertilized control showed the minimum marketable tuber yields of 11.9, 12.16 and 12.01 $\mathrm{t} / \mathrm{ha}$ at the station, on-farm and in combined over sites, respectively.

In general, the total tuber yields of potato were the highest at the highest level of organic treatments and the lowest at the lowest level of organic treatments. This was because of the availability of high amount of soil nutrients from the combination manure. The combination of manure at $5 \mathrm{t} / \mathrm{ha}$ FYM + $2.5 \mathrm{t} / \mathrm{ha}$ FSM contains the maximum amount of soil nutrients with $121,40.5 \& 73 \mathrm{t} /$ ha of NPK, respectively, than other treatments (Appendix 2). Several research reports supported the importance of organic fertilizer in replenishing the degraded soil in potato yield. According to Swadija (2013) the highest total tuber yield of $23.49 \mathrm{t} /$ ha was obtained from $6.5 \mathrm{t} / \mathrm{ha}$ of FYM compared to the lowest level. Similarly, Amir et al. (2012) argue that the tuber yield of potato was increased by increasing the level of FYM, but supplement above $20.9 \mathrm{t} / \mathrm{ha}$ did not increase the tuber yield. This is also supported by Najm et al. (2013) who showed that potato tuber yields of $20 \mathrm{t} / \mathrm{ha}$ were the highest at $15 \mathrm{t} / \mathrm{ha}$ of FYM than its lower level. Amber et al. (2011) also showed the yield attributing characters of potato were significantly augmented by annual application of organic treatments and showed the highest increase at higher rate of organic fertilizer compared to unfertilized control. Furthermore, Amir et al. (2006) also suggested that maximum tuber yield of $35.34 \mathrm{t} / \mathrm{ha}$ was recorded at maximum rates of farmyard manure (20 t/ha) whereas amounts of tuber yields of $25 \mathrm{t} / \mathrm{ha}$ were the minimum at the lower rate of FYM at $5 \mathrm{t} / \mathrm{ha}$. Consistent with this suggestion, Stefano et al. (2010) confirmed that potato preceded by clover showed 35\% yield increase than winter wheat.

Unlike the main effect of organic treatment, crop rotation system $(\mathrm{T})$ did not bring about significant $(P<0.05)$ difference on the marketable and total yield of potato in 2014 (Table 4). However, relatively greater total yield of potato (18.8 t/ ha) was recorded when potato was followed by sole lupine at on-station. In the same way, the total tuber yield of potato was the highest with 18.9 and $18.85 \mathrm{t} / \mathrm{ha}$ at on-farm and in combined over sites, respectively. However, the rotation system of potato followed by wheat undersowing lupine showed the lowest total tuber yield of 18.2.18.8 and $18.55 \mathrm{t} / \mathrm{ha}$ at the station, on farm and in combined over sites, respectively. A similar scenario was recorded on the unmarketable 


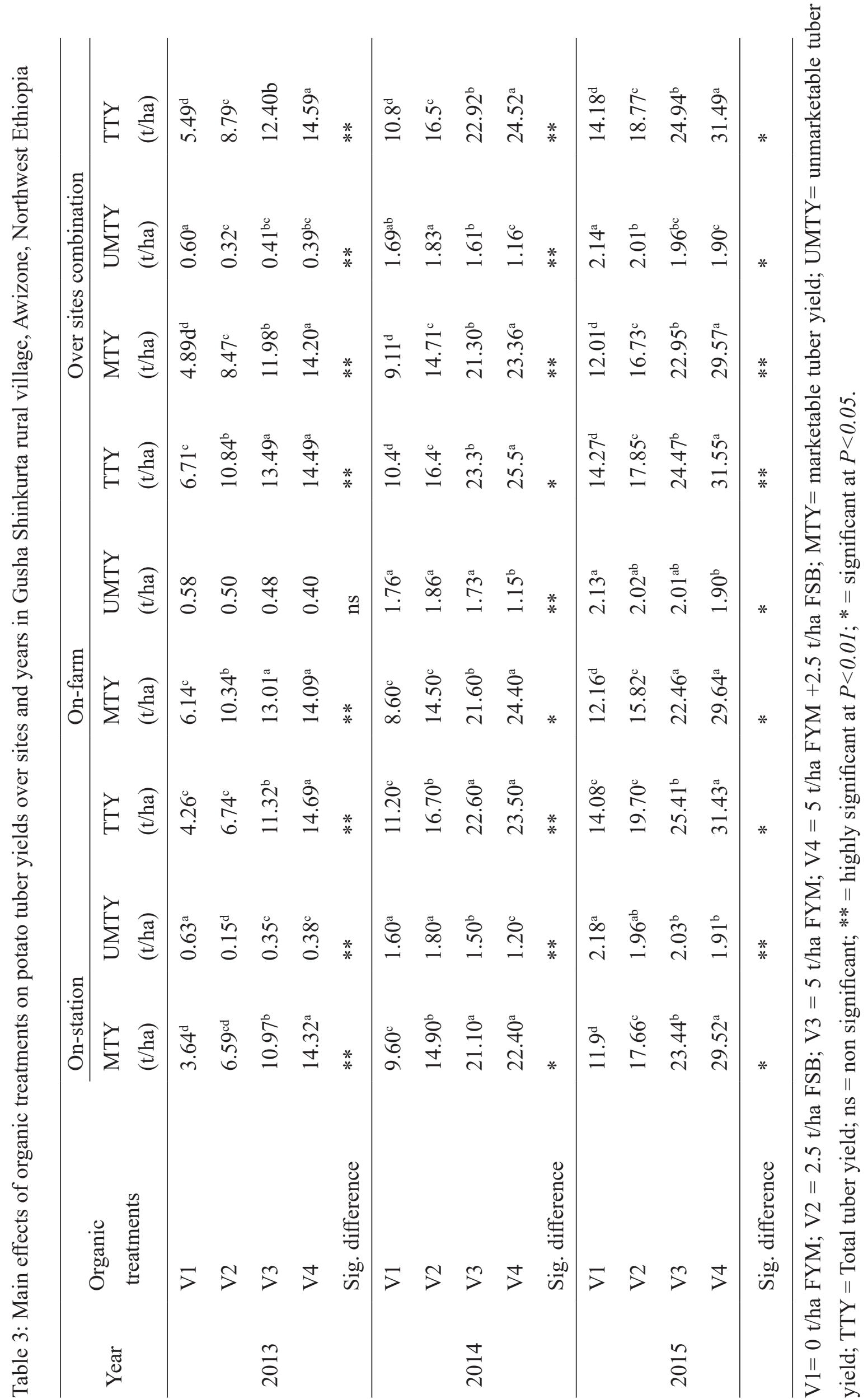


yield of potato (Table 4). Potato followed by sole lupine showed the highest total tuber yield at both sites and in combined over sites. Lack of significant change between two rotation systems was observed because the influence of the rotation system was minimal to bring significant change on tuber yields of potato (Table 4). Lupine both in undersowing and in sole cropping system gave an equivalent size of biomass to influence the succeeding crop similarly.

Table 4: Main effects of crop rotation on potato tuber yields over sites and years in Gusha Shinkurta rural village, Awi Zone, Northwest Ethiopia

\begin{tabular}{|c|c|c|c|c|c|c|c|c|c|c|}
\hline \multirow[b]{2}{*}{ Year } & \multirow[b]{2}{*}{$\begin{array}{l}\text { Crop } \\
\text { rotation system }\end{array}$} & \multicolumn{3}{|c|}{ On-station } & \multicolumn{3}{|c|}{ On-farm } & \multicolumn{3}{|c|}{ Over sites combination } \\
\hline & & $\begin{array}{l}\text { MTY } \\
\text { (t/ha) }\end{array}$ & $\begin{array}{l}\text { UMTY } \\
\text { (t/ha) }\end{array}$ & $\begin{array}{l}\text { TTY } \\
\text { (t/ha) }\end{array}$ & $\begin{array}{l}\text { MTY } \\
\text { (t/ha) }\end{array}$ & $\begin{array}{l}\text { UMTY } \\
(\mathrm{t} / \mathrm{ha})\end{array}$ & $\begin{array}{l}\text { TTY } \\
\text { (t/ha) }\end{array}$ & $\begin{array}{l}\text { MTY } \\
(\mathrm{t} / \mathrm{ha})\end{array}$ & $\begin{array}{l}\text { UMTY } \\
\text { (t/ha) }\end{array}$ & $\begin{array}{l}\text { TTY } \\
\text { (t/ha) }\end{array}$ \\
\hline \multirow{3}{*}{2014} & $\mathrm{R} 1$ & 16.69 & 1.52 & 18.2 & 17.28 & 1.60 & 18.80 & 17.00 & 1.56 & 18.55 \\
\hline & $\mathrm{R} 2$ & 17.27 & 1.53 & 18.8 & 17.25 & 1.65 & 18.90 & 17.26 & 1.59 & 18.85 \\
\hline & Sig. difference & ns & ns & ns & ns & ns & ns & ns & ns & ns \\
\hline \multirow{3}{*}{2015} & R3 & $22.00^{\mathrm{a}}$ & 2.03 & $24.02^{\mathrm{a}}$ & $21.81^{\mathrm{a}}$ & 2.04 & $23.81^{\mathrm{a}}$ & $21.9^{\mathrm{a}}$ & $2.00^{\mathrm{a}}$ & $23.91^{\mathrm{a}}$ \\
\hline & $\mathrm{R} 4$ & $19.25^{\mathrm{b}}$ & 2.01 & $21.29^{\mathrm{b}}$ & $18.21^{\mathrm{b}}$ & 1.99 & $20.26^{\mathrm{b}}$ & $18.73^{\mathrm{b}}$ & $2.04^{\mathrm{a}}$ & $20.77^{b}$ \\
\hline & Sig. difference & $*$ & ns & $* *$ & $*$ & ns & $* *$ & $*$ & ns & $*$ \\
\hline
\end{tabular}

$\mathrm{R} 1=$ wheat undersowing lupine-potato; R2 = lupine-potato, R3 = wheat-clover-potato; R4 = cloverwheat under sown lupine-potato; MTY= marketable tuber yield; UMTY= unmarketable tuber yield; $\mathrm{TTY}=$ Total tuber yield; $\mathrm{ns}=$ non significant; $* *=$ highly significant at $P<0.01$; $*$ significant at $P<0.05$.

However, crop rotation system $(\mathrm{T})$ resulted in significant $(P<0.01)$ difference on tuber yield of potato in 2015 (Table 4). Potato followed by clover and wheat showed the highest marketable and total potato tuber yield than potato followed by wheat under sown lupine and clover. At the station, the maximum marketable potato tuber yield $(22 \mathrm{t} /$ ha) was recorded when potato was followed by clover and wheat. Similarly, the marketable yield (21.81 t/ha) recorded at $\mathrm{R} 3$ was maximum at onfarm conditions. Tuber yield in combined over sites showed similar trends as the individual sites where the marketable yield $(21.81 \mathrm{t} / \mathrm{ha})$ was higher than other treatments. However, the lowest marketable yields of 19.2518 .21 and $18.73 \mathrm{t} / \mathrm{ha}$ were recorded when potato was followed by wheat under sown lupine and clover (R1) at the station, on-farm and in combined over sites, respectively. Similar scenario was observed on total tuber yield of potato. Potato followed by clover and wheat rotation system showed the highest total potato tuber yields of 24.02, 23.81 and 23.91 t/ha at 
station, on-farm and in combined over location, respectively. However, potato followed by wheat under sown lupine and clover (R1) showed the lowest total tuber yields of 21.29, 20.26 and 20.77 t/ha at station, on-farm and in combined over sites, respectively. The results indicate that planting of green manure crops especially clover as preceding crop enhances soil nutrients and improves potato yield tremendously. This is in agreement with the research results of Malihe et al. (2015) who reported that green manure as preceding crop improved the tuber yield of potato by improving the fertility and ameliorating soil physical properties. Similarly, Eugenija et al. (2014) reported that maximum tuber yield of potato was obtained after clover than barley rotation system. Malihe et al. (2015) also found that potato plants grown in plots following common vetch and faba bean produced $12.7 \%$ and $15.0 \%$ more tuber yield, respectively, compared with that of winter wheat. Similarly, Stefano et al. (2010) indicated that clover green manure and farmyard manure substantially increased the total yield by $22.5 \%$ and $25.1 \%$, respectively, over the untreated control. Similarly, Sanderson and Macleod (1993) reported that tuber yields were lower following barley than following lupine green manure.

Like the main effects of organic treatment (M), the interaction $(\mathrm{M} \times \mathrm{T})$ effect of organic treatment and crop rotation system showed significant $(P<0.001)$ difference on tuber yields of potato in 2014 and 2015 (Table 5).The highest marketable and total tuber yield of potato was recorded at the interaction effects of $5 \mathrm{t} / \mathrm{ha}$ of FYM $+2.5 \mathrm{t} / \mathrm{ha}$ FSB and potato followed by sole lupine (R2V4) compared to all other treatment combinations in 2014. Thus, the total tuber yields of 24.2, 25.4 and $24.8 \mathrm{t} / \mathrm{ha}$ at on-station, on-farm and in combined over locations, respectively, were the highest by any standards compared to other treatment combinations. Marketable yield also showed similar trend to the total yield of potato (Table 5). However, the interaction of unfertilized control and wheat under sown lupine showed the smallest tuber yield in both sites and in combined over sites. The total tuber yields of 10, 11 and $10.5 \mathrm{t} / \mathrm{ha}$ at station, on-farm and in combined over location, respectively, were lower by any standards. In general, an increase in potato tuber yield due to variation in cropping system and rate of manure indicted that soil nutrients were improved by the system of soil fertilization. This was because of the availability of the highest amount of soil nutrients from the interaction of $5 \mathrm{t} / \mathrm{ha}$ of FYM $+2.5 \mathrm{t} / \mathrm{ha}$ FSB and due to the fact that potato was followed by sole lupine with superior quantity of $179,50.3$ \& $99.4 \mathrm{~kg} / \mathrm{ha}$ of NPK, respectively, than other treatments (Appendix2).

In addition, the interaction $(\mathrm{M} \times \mathrm{T})$ effects of organic treatment and crop rotation system showed significant $(p<0.001)$ difference on tuber yield of potato in 2015 (Table 5). Maximum marketable and total tuber yield were recorded at the highest levels of organic treatment and sound crop rotation system, and become the minimum on unfertilized control and less sound rotation systems. The highest marketable potato yield (32.5 t/ha) was recorded at the interaction effects of 5 t/ha FYM $+2.5 \mathrm{t} / \mathrm{ha}$ FSM and potato followed by clover and wheat at the station. Incoherent with the station, marketable yield (34.02 t/ha) was also highest at on-farm conditions. Similarly, the marketable yield (33.28 t/ha) was the peak in combined over sites. Following this treatment, the interaction effects of 5 t/ha FYM +2.5 t/ha FSM and potato followed by wheat undersowing lupine and clover showed the highest marketable yield of 26.5, 25.28 and $25.88 \mathrm{t} / \mathrm{ha}$ at the station, on farm and 


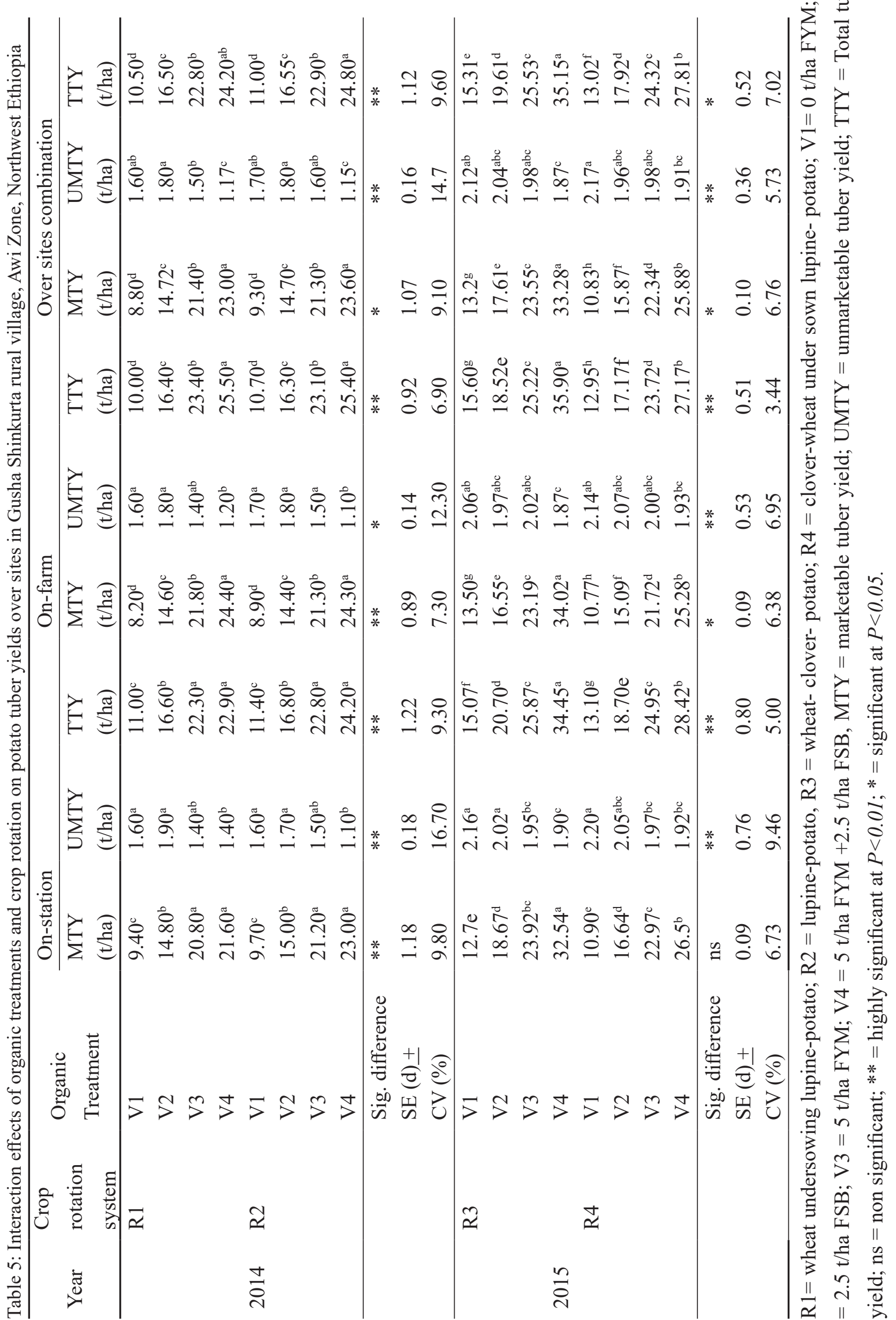


in combined over sites, respectively. However, minimum marketable tuber yield was recorded on the interaction effects of unfertilized control and potato followed by wheat under sown lupine and clover rotation system (Table 5). The total tuber yield of potato also varied with the same trend to the marketable yield of potato. Total tuber yield of potato was highest at the highest levels of organic treatment and sound rotation system but was lowest at the lowest levels organic treatment and less sound rotation system. Thus, the highest total potato tuber yield (34.45 t/ha) was recorded at the interaction effects of $5 \mathrm{t} / \mathrm{ha} F Y M+2.5 \mathrm{t} /$ ha FSM and potato followed by clover and wheat (R3V4) in the station. In the same way, the total tuber yield (35.90 t/ha) recorded was maximum at on-farm conditions. The combined over sites still showed the highest total tuber yield (35.15 t/ ha) compared to other treatment combinations. Following the above treatment, the interaction effects of $5 \mathrm{t} / \mathrm{ha} \mathrm{FYM}+2.5 \mathrm{t} / \mathrm{ha}$ of FSM and potato followed by clover and wheat (R4V4) showed greater total potato tuber yield next to R3V4. The total tuber yields were $28.42,27.17$ and $27.81 \mathrm{t} / \mathrm{ha}$ at the station, on-farm and in combined over sites, respectively. However, the interaction effects of unfertilized control and potato followed by wheat under sown lupine and clover (R2V1) rotation systems showed the lowest total tuber yield of $13.1,12.95$ and $13.02 \mathrm{t} / \mathrm{ha}$ at the station, on-farm and in combined over sites, respectively. The harvesting of the highest yield at the higher rate of organic treatment and potato immediately followed by clover enriched the soil with nitrogen and other nutrients to fulfill the nutrient demand of the crop (Appendix 3).

In general, the yield of potato showed increasing trends in response to organic treatments and crop rotation system year after year (Figure 3). Tuber yields of potatoes were the lowest in the first year, intermediate in the second and hit the highest in the third year across each treatment. For example, the maximum level of organic treatment that showed the highest potato tuber yield across all years produced the lowest potato tuber yield (14.59 t/ha) in the first year, an intermediate potato tuber yield $(24.8 \mathrm{t} / \mathrm{ha})$ when preceded by sole lupine in the second year and showed maximum potato tuber yield $(35.15 \mathrm{t} / \mathrm{ha})$ when integrated with potato followed by clover and wheat rotation system in the third year. The yield advantage of the third season increased by $140 \%$ and $41 \%$ compared with the yield of potato in the first and the second year, respectively.

The appreciable increasing trend of potato yield over the three years could arguably be generalized due to the carryover effects of the annual application of organic inputs and residue from rotation system. This result is in line with Manoj et al. (2013) who reported that long-term organic treatment either from the preceding crop or FYM improves steadily potato yield over the years with the lowest at the beginning of project phase and the highest at the end of the fifth year. Similarly, Fan et al. (2005) showed that long-term additions of organic materials definitely arrested potato yield declines and improved yield year after year. Furthermore, Amber et al. (2010) reported that tuber yield of potato significantly increased year after year through applications of composted dairy manure and proper rotation system. Comparable yield trend was also observed in ranges of field crops including wheat. Mando et al. (2005) demonstrated that greater grain and straw yields of wheat were recorded on long-term manure input than on the unfertilized control. Similarly, Hatch et al. (2008) in their long-term study demonstrated that maize straw and grain yield showed the largest increase at the end of long term manure fertilization. 


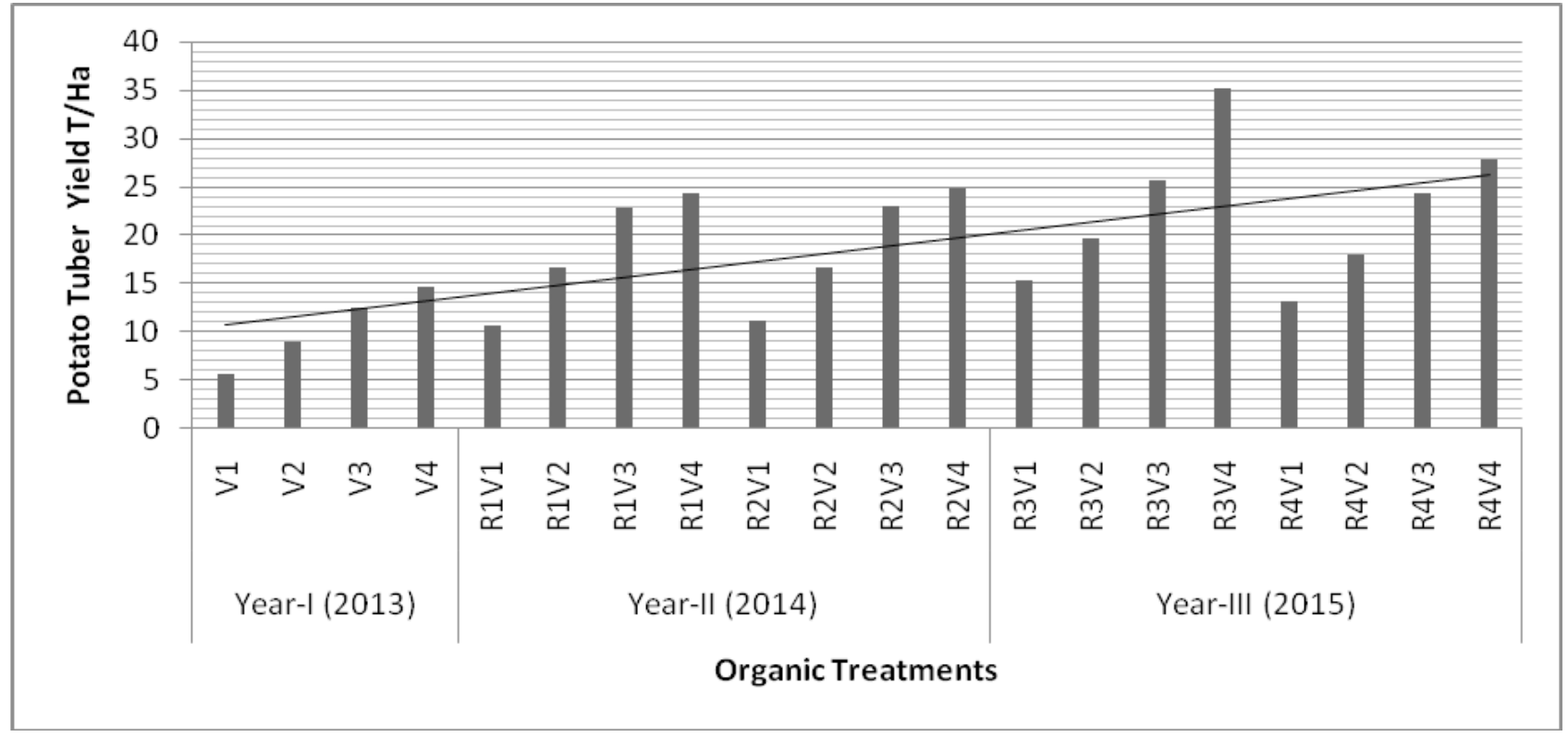

$\mathrm{V} 1=0$ t/ha FYM; V2 =2.5 t/ha FSB; V3 = 5 t/ha FYM; V4 $=5$ t/ha FYM +2.5 t/ha FSB; R1= wheat undersowing lupine-potato; R2 = lupine-potato, R3 = wheat-clover-potato; R4 = clover-wheat under sown lupine-potato

Figure 3: The tuber yield trend of potato ( $\mathrm{t} / \mathrm{ha})$ in response to organic treatments and rotation system from 2013 to 2015

\section{CONCLUSIONS}

The variation in level of organic manure and crop rotation system and their interaction effects showed the strongest influence on tuber yield of potato. Application of different levels of organic treatments influenced the yield of potato differently. Potato tuber yield was the highest at the maximum level of organic treatments and the smallest at the lowest level of organic treatments. Similarly, growing green manures as a preceding crop substantially improved the yield of potato. Potato tuber yield was greater when the potato was immediately followed by clover and sole lupine than undersowing forms. In addition, the interaction effects of a combination of manure and sound crop rotation system synergistically improved the tuber yield of potato. Maximum potato tuber yield was recorded at interaction effects of $5 \mathrm{t} / \mathrm{ha} \mathrm{FYM}+2.5 \mathrm{t} / \mathrm{ha} \mathrm{FSB}$ and when potato was followed by clover and wheat compared to other treatments combinations. This was certainly due to a high level of soil nutrient replenishing rate at the maximum level of organic treatments and sound rotation system on the longest term of rotation. Hence, it could be concluded that even though separate application of organic treatment and rotation system has a positive effect on yield performance of potato, their combined use has more beneficial effect in improving potato yield. Finally, selection of diffeent types of green manure that better fit with the agro-ecosystem of the district could be an intervention in the future. 


\section{ACKNOWLEDGMENTS}

The authors wish to acknowledge The Agricultural Research for Development (ARD) and Dimension of European Research Area (ERA) for funding the project.

\section{REFERENCES}

Ali, N and Juthery, H. (2015). The combined effect of different fertilizer sources and irrigation method on potato and water productivities under iraqi conditions of agriculture. International Journal of Recent Scientific Research 6(8): 5569-5572.

Amare, H., Joerg, E and Priess, A. (2006). Smallholders' soil fertility management in the central highlands of Ethiopia: Implications for nutrient stocks, balances and sustainability of agro-ecosystems. Nutrient Cycling in Agro Ecosystems 75(3):135-146.

Amber, D., Olsen, L and Anna, M. (2010). Residual effects of fresh and composted dairy manure application on potato tuber yield. America Journal of Potato Research 88(4): 324-332.

Amir, A., Mohammad, R., Haj, S., Faezeh, F., Mohammad, T and Alireza, R. (2012). Effect of integrated nutrient management of nitrogen fertilizer and cattle manure on leaf chlorophyll and tuber yield of potato. Communications in Soil Science and Plant Analysis 43(2): 912-923.

Eugenija, B., Almantas, R., Rita, A., Audrius, K., Zita, M., Danuta, R., Jelena, T and Liudmila, T. (2014). Effects of ecological farming systems: five year crop rotations on crop productivity and properties of haplic luvisol. Journal of Food, Agriculture and Environment 4(11): 1137 - 1142.

Fan, T., Stewart, B., Yong, W., Junjie, L and Guangye, Z. (2005). Long-term fertilization effects on grain yield, water-use efficiency and soil fertility in the dryland of Loess Plateau in China. Agriculture Ecosystems and Environment 106(4):313-329.

FAOSTAT (2013). Agricultural data provisional and production indices. FAO, Italy.

Gildemacher, P., Kaguongo, W., Ortiz, O., Tesfaye Amogne and Woldegiorgis Gebrie. (2009). Improving potato production in Kenya, Uganda and Ethiopia: A system diagnosis. Potato Research Journal 52(1): 173-205.
Goffart, J and Olivier, M. (2008). Potato crop nitrogen status assessment to improve nitrogen fertilization management and efficiency: past-present-future. Journal of Potato Research 51: 355-383.

Hatch, D., Sacco, D., Bertora, C and Grignani, C. (2008). Changes in chemical and biochemical soil properties induced by 11 year repeated additions of different organic materials in maize-based forage systems. Soil Biology and Biochemistry 40(3): 608-615.

Adane Herpa, Meuwissen Mola, Tesfaye Agajie, Lommen, W., Lansink, A and Tari, A. (2010). Analysis of seed potato systems in Ethiopia. America Journal of Potato Research 78(6): 537552.

Malihe, M., Mohammad, F., Alireza, K., Mohsen, N and Mehdi, T. (2015). Farmyard manure application of potato with three level of nitrogen fertilizer. International Journal of Farming and Allied Sciences 4(6): 536-540.

Mando, A., Ouattara, B., Sédogo, M., Stroosnijder, L., Ouattara, K., Brussaard, L and Vanlauwe, B. (2005). Long-term effect of tillage and manure application on soil organic fractions and crop performance under Sudano-Sahelian conditions. Soil and Tillage Research 80(2):95-101.

Manoj, K., Baishya, L., Ghosh, M and Ghosh, V. (2013). Effects of organic manures, chemical fertilizers and bio-fertilizers on growth and productivity of rain fed potato in the eastern himalayas. Journal of Plant Nutrition and Agriculture 36: 1065-1082.

Mclea, E. (1965). Methods of Soil Analysis: McGrawHill, New York.

Mohammed Gedefaw and Teshome Soromessa (2015). Land degradation and its impact in the highlands of Ethiopia: Case study in Kutaber Wereda, South Wollo, Ethiopia. Global Journal of Agriculture and Agricultural Sciences 3(8):288-294.

Murphy, H. (1968). In report on fertility status on some soils of Ethiopia. Advances in Plants \& Agriculture Research 4(4):7-14.

Najm, A., Haj, M and Fazeli, R. (2010). Effect of utilization organic and inorganic nitrogen fertilizer sources on potato shoots, dry matter, leaf area index and plant height at middle stage of growth. International Scholarly and Scientific Research and Innovation 8(11): 25-31.

Ndayegamiye, A., Nyiraneza, J., Grenier, M., Bipfubusa, M and Drapeau, A. (2017). The benefits of crop 
rotation including cereals and green manures on potato yield and nitrogen nutrition and soil properties. Advanced Crop Science 5(2): 279-291.

Ruser, C., Mogia, M., Dahi, L and Allan, D. (2007). Exploring the benefits of organic nutrient sources for crop production and soil quality. Hort Technology Jounal of Assah 14(2):24-31.

SAS. (2002). Statistical software analysis using the SAS System. Cary, NC, SAS Institute Inc.

Sayed, F., Hassien, A., Muhamed, $\mathrm{M}$ and Ahimed, A. (2014). Growth, yield and nutrient concentration of potato plants. American-Eurasian Journal of Agriculture and Environmental Science 7(14): 36-43.

Stefano, C., Corrado, C., Daniele, A., Paolo, B and Fite, M. (2010). Interactions between green manure and amendment type and rate: effects on organic potato and soil mineral nitrogen dynamic. Journal of Food, Agriculture and Environment 8(2): 537-543.

Tilahune Amedie, Edris Guta and Takele Belay (2007). Reversing the degradation of arable land in Ethiopian highlands. Managing African Soil, London, UK.

Yazie Chanie (2009). Characterization of potato production, marketing and utilization in Northwestern Amhara Region. Annual Statistical Bulletin, Bahir Dar, Ethiopia.

Yihnew Gebreslasie (2002). Selected chemical and physical characteristics of soils of Adet Agricultural Research Center and its testing sites. Ethiopia Journal of Neutral Resource 4: 203-206. 


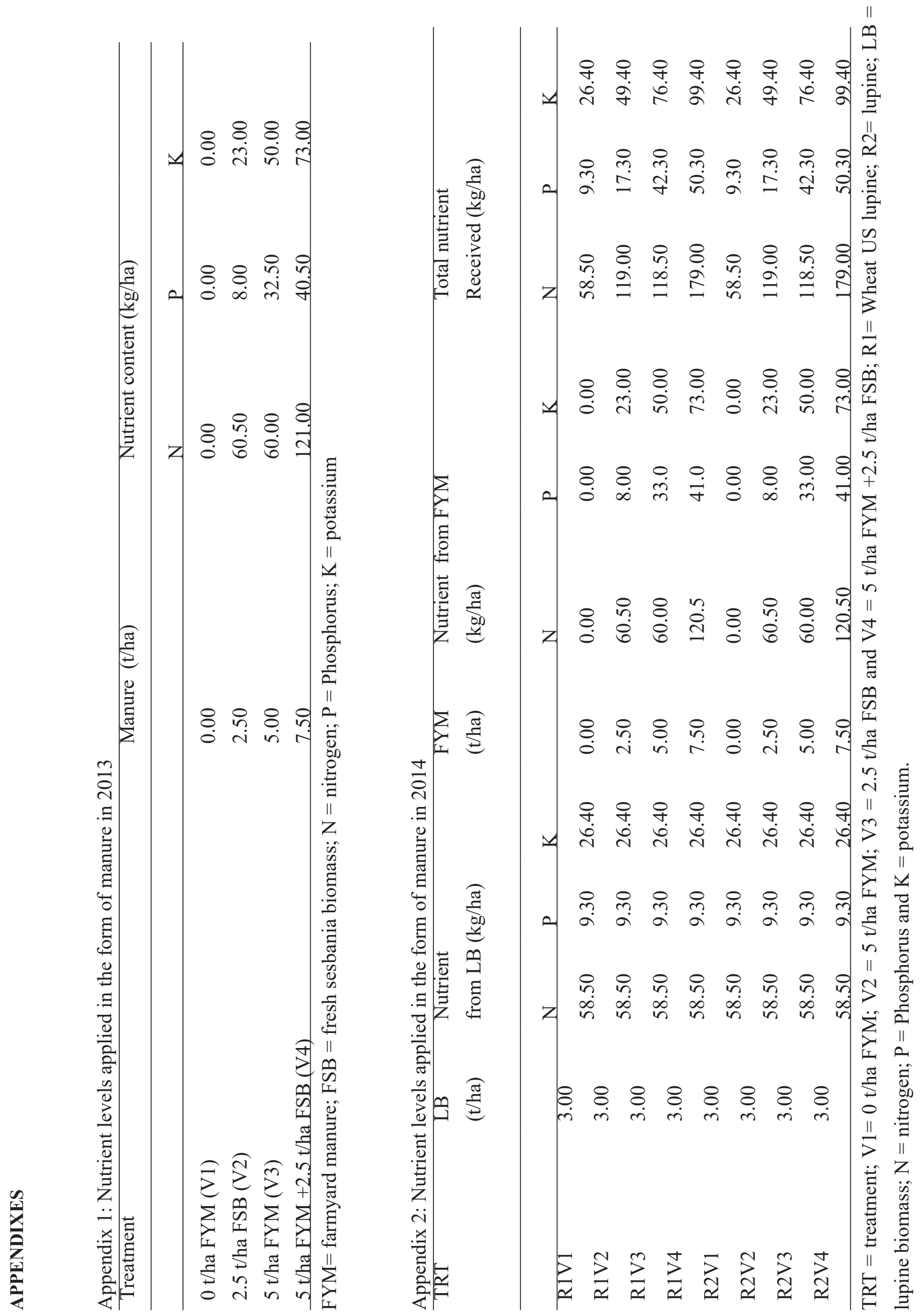




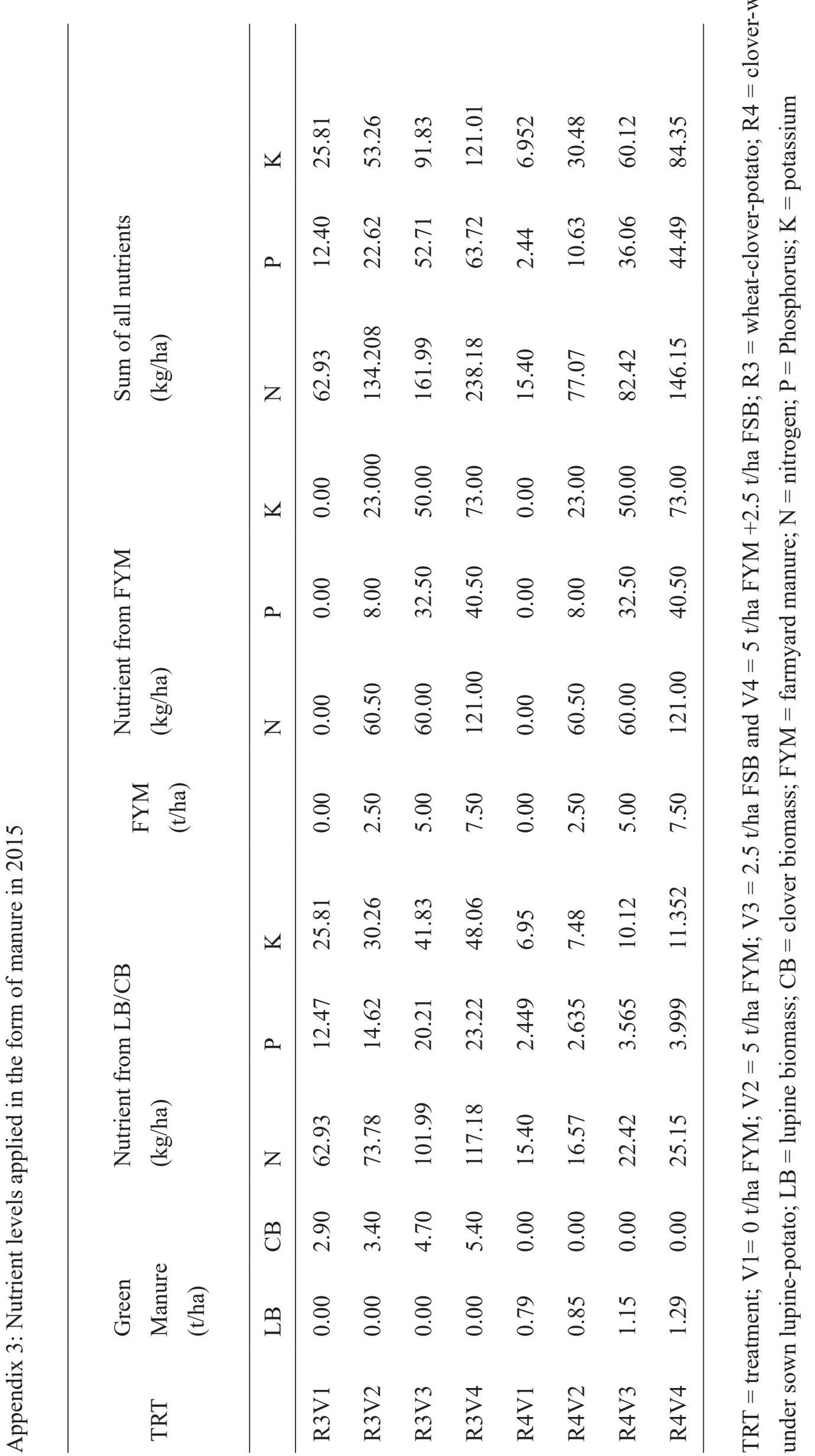

